Article

\title{
An Industrial Scale, Mechanical Process for Improving Pellet Quality and Biogas Production from Hazelnut and Olive Pruning
}

\author{
Leonardo Bianchini ${ }^{1, *(\mathbb{D})}$, Paolo Costa ${ }^{1}$, Pier Paolo Dell'Omo ${ }^{2}$, Andrea Colantoni ${ }^{1}$ (D), Massimo Cecchini ${ }^{1} \mathbb{D}$ \\ and Danilo Monarca ${ }^{1}$ (D) \\ 1 Department of Agriculture and Forest Sciences, Tuscia University (DAFNE), Via S. Camillo de Lellis snc, \\ 01100 Viterbo, Italy; castauniv30@gmail.com (P.C.); colantoni@unitus.it (A.C.); cecchini@unitus.it (M.C.); \\ monarca@unitus.it (D.M.) \\ 2 Department of Astronautical, Electrical and Energy Engineering (DIAEE), University La Sapienza, \\ Via Eudossiana 18, 00184 Rome, Italy; paolo.dellomo@uniroma1.it \\ * Correspondence: 1.bianchini@unitus.it; Tel.: +39-076-1135-7357
}

Citation: Bianchini, L.; Costa, P.; Dell'Omo, P.P.; Colantoni, A.; Cecchini, M.; Monarca, D. An Industrial Scale, Mechanical Process for Improving Pellet Quality and Biogas Production from Hazelnut and Olive Pruning. Energies 2021, 14, 1600 https://doi.org/10.3390/en14061600

Academic Editor: Dino Musmarra

Received: 25 February 2021

Accepted: 11 March 2021

Published: 13 March 2021

Publisher's Note: MDPI stays neutral with regard to jurisdictional claims in published maps and institutional affiliations.

Copyright: (c) 2021 by the authors. Licensee MDPI, Basel, Switzerland. This article is an open access article distributed under the terms and conditions of the Creative Commons Attribution (CC BY) license (https:/ / creativecommons.org/licenses/by/ $4.0 /)$.

\begin{abstract}
The effects of a mechanical process on the solid fuel quality and anaerobic biodegradability of hazelnut and olive pruning were determined. The feedstock was treated using a two-stage dry milling process, followed by fractionation into four different products. The coarser products from the processing of both the raw materials, named $\mathrm{C}$ and $\mathrm{M}$, were notable for the high reduction in both the ash and nitrogen content. Therefore, for hazelnut, they met the requirement of the EN ISO 17225-2 standard for both the industrial and residential pellets, whereas C and M from olive processing met the requirements only for the industrial pellet. The raw materials and the finest products from processing, named F1 and F2, were anaerobically digested in batch reactors under mesophilic conditions. The F2 product from hazelnut processing reached a methane yield of $118.1 \mathrm{Nm}^{3} \mathrm{t}_{\mathrm{VS}}{ }^{-1}$, corresponding to a $+70.1 \%$ gain over the untreated substrate, whereas $\mathrm{F} 2$ from olive pruning processing reached $176.5 \mathrm{Nm}^{3} \mathrm{t}_{\mathrm{VS}}{ }^{-1}$, corresponding to a methane yield gain of about $+93.5 \%$ over the untreated raw material. These results suggest that the investigated process could be successfully used to improve the quality of pruning and establish new markets for them.
\end{abstract}

Keywords: pruning; anaerobic digestion; biogas; pellet; hazelnut; olive

\section{Introduction}

One of the reasons for the increased interest in renewable energy production is the concern about the use of fossil fuels and the environmental damage they cause.

On 10 January 2007, the European Commission drew up a long-term vision for the EU (European Union) to generate energy from renewable sources [1]. This led to the proposal to establish a target by the year 2020 that $20 \%$ of the overall energy consumption in the EU shall be from renewable sources. In addition, it proposed establishing, also by 2020, that a binding $10 \%$ of the overall energy consumption in the transport sector shall be from renewable sources.

In 2012, the total EU27 biomass supply for electricity, heating and cooling amounted to 103.3 Mtoe, accounting for about two-thirds of all renewable energy consumption in the EU, and it is projected to increase to 132 Mtoe by 2020. Therefore, wood for energy and materials will become scarcer, and new resources will be necessary to meet the increasing demand through domestic supply [1].

In Italy alone, the annual amount of residue derived from the pruning of olive and hazelnut groves, vineyards and other orchards has been estimated to 3.7 million tons of dry matter. Among them, 1.7 million tons are reasonably available for energetic exploitation [2].

Currently, mulching or briquetting pruning residues is the norm, with an estimated respective cost of 100 and $200 € \mathrm{ha}^{-1}$ [3], so they are not considered an additional income 
opportunity. However, the development of harvesting equipment improves technical and economic sustainability $[4,5]$. Therefore, biomass from pruning may represent a real economic opportunity and fuel source in Italy [6,7] and beyond [8].

Compared to wood, prunings have a higher ash content and a higher concentration of metals, which influence emissions and cause problems during combustion [9]. Dust emissions consist of both carbonaceous particles and alkali metals, sulphur and chlorine [10-12]. Inorganic species in biomass fuels, such as silica, alkali oxides and salts, can increase ash deposition on the heat transfer surfaces of boilers [11,12]. High concentrations of sulphur $(\mathrm{S})$, chlorine $(\mathrm{Cl})$ and nitrogen $(\mathrm{N})$ increase the emissions of sulphur dioxide $\left(\mathrm{SO}_{2}\right)$, hydrogen chloride $(\mathrm{HCl})$ and nitrogen oxides $\left(\mathrm{NO}_{\mathrm{x}}\right)$, respectively [12-14]. In addition, incomplete combustion of organic material in the presence of chlorine causes the formation of dioxins [11,13].

The emission of particulate matter generated by the combustion of pruning can be controlled if medium to large boilers are used, which are usually equipped with flue gas control systems. Nevertheless, these medium-large scale plants require a large procurement basin; thus, transport distances are excessive for pruning residues. The economic sustainability rapidly decreases for transport distances greater than $10 \mathrm{~km}$, mostly be-cause of the low bulk density of the resulting biomass and the relatively low hourly productivity of the harvesting machines $[13,14]$.

As an alternative, pruning biomass can be processed into pellets. Commercial pellets made from fruit tree pruning have been studied $[13,15]$. They had very good characteristics but also had the disadvantages of higher ash content and $\mathrm{NO}_{\mathbf{x}}$ and $\mathrm{SO}_{2}$ emissions. The high ash content lowers the calorific value and negatively affects the milling and pelletizing equipment [15].

Biochemical conversion of pruning into biogas is also of interest, because of its high thermodynamic efficiency [16,17].

In October 2014, the Ministry of Economic Development introduced the obligation to prioritize placing the so-called "advanced biofuels", i.e., biofuels, on the Italian fuel market, including biomethane, which are produced exclusively from specific feedstocks, such as straw, dedicated lignocellulosic crops and residual woody biomass. The mandatory share of advanced biofuels for the year, 2018, is set at $1.7 \%$ of energy demand in the transport sector, rising to $2 \%$ in 2022 [18].

In Italy, the GSE (Gestore dei Servizi Energetici, Energy Services Manager) has the task of preparing a report on the monitoring of the degree of achievement of the national and regional targets in terms of the share of gross final energy consumption from renewable sources, at an overall level and with reference to the electricity, heat and transport sectors. In Italy in 2018, energy production from solid biomass amounted to 564 ktoe and 718 ktoe for the biogas for the electricity sector. While consumption for the thermal sector 6458 ktoe for solid biomass and 54 ktoe for biogas and bio-methane. This showed an increasing trend over an analysed period from 2012 to 2018. [19].

The use of biomethane would contribute to the reduction of greenhouse gas emissions to a much greater extent $(>80 \%)$ than the minimum required by the European Directive [18] and can be easily distributed through the existing pipeline network.

Woody biomass is not widely used for methane production because of its low biodegradability, given the high content of structural carbohydrates and lignin. Therefore, to improve biodegradability, a pre-treatment step is necessary to weaken the lignocellulosic structure and increase the surface area for enzymatic attack. There are many studies on the use of olive mill solid waste and hazelnut shells [20,21]. Many studies are also underway to improve the digestion process of these products. Among them, pre-treatment with organic solvents gave highly effective results [22,23]; however, in the opinion of the authors, it would take enormous sizes-over 200,000 t/year of biomass-to ensure the viability of the installation. Hydrothermal and dilute acid pre-treatment of olive and vineyards pruning gave poor results, also using commercial enzyme addition in the digestion sludge; steam explosion proved to be the more effective pre-treatment, especially for olive pruning; 
however, the authors did not compare the results with those obtained for the untreated material [24].

Milling steps following one another have also been considered as a pre-treatment procedure in the lignocellulose bio-refinery; however, currently, they are not considered cost-effective because of the high energy demand [25]. Nevertheless, there is increasing research interest in mechanical pre-treatment processes due to the advantages of speed and absence of effluent.

Dry milling, and subsequent fractionation by sieving and/or and density separation, is a well-known technique in the food industry, used to obtain several specific ingredients, especially proteins, from a single feedstock, such as cereals and legumes [26,27].

Dry milling and fractionation of corn have also been proposed to recover germ and fibre as valuable coproducts prior to fermentation for ethanol production [28].

Disc milling and subsequent sieving were used to separate wheat straw into two fractions, which were then pre-treated with dilute acid. The classification was particularly effective with respect to the separation of the non-lignocellulosic components, i.e., protein and extractives [29].

To the best of our knowledge, dry fractionation of wood, and particularly of pruning, in order to improve both their quality as solid fuel and their anaerobic degradability has never been investigated in the literature before.

The aim of this study was to assess the performance of an industrial-scale device used to mill and classify pruning into four different products, in order to obtain betterquality solid fuels and fractions with improved anaerobic degradability. Through a detailed analysis of the chemical and elemental composition and a set of anaerobic digestion and calorimetric experiments, both the methane yield and the heat from combustion of the materials were determined. The quality of the solid fuels was also assessed, particularly concerning their ash and nitrogen content. Lastly, an evaluation of the energy balance of the process was carried out.

\section{Materials and Methods}

\subsection{Harvesting and Processing}

Hazelnut and olive prunings were harvested in winter 2020 in the Viterbo province, Central Italy, by a COMBI TR160 pruning harvester. The baled raw materials were then stored in a covered and ventilated area to be naturally dried until early summer 2020 . The dried raw materials were chopped by a knife mill to an average length of about $30 \mathrm{~mm}$; a portion of these chips was used as a reference.

An industrial-scale device designed for milling and fractionating feedstock with a high dry matter content $(>70 \%)$ was used to process the chips. Included was a two-stage mill: the first acts by impact, maximizing the number of impacts to achieve a significant breakage, and the second exerts strong shear actions (Figure 1) [30]. The milled material is then sieved through a plan sifter into three fractions, namely C (Coarse), M (Medium) and $\mathrm{F}$ (Fine). The fine fractions are further classified according to their dimensions, shape and density, into two fractions (named F1 and F2) through a centrifugal classifier (Table 1).

Thirty kilograms of chips of both materials were then processed in the previously described device, obtaining in each case four different products. A screw conveyer fed the mill at a constant mass flow rate, which was $990 \mathrm{~kg} \mathrm{~h}^{-1}$ and $1100 \mathrm{~kg} \mathrm{~h}^{-1}$ for hazelnut and olive pruning, respectively. A wattmeter (MTME-485, ABB-SACE, Italy) was used to observe the power absorbed by the device; power, supply voltage, current and time were recorded at one-second intervals. By integrating the area under the power demand curve by the total time required to grind the $30 \mathrm{~kg}$ sample, the specific energy $\left(\mathrm{MJ} \mathrm{kg}^{-1}\right)$ required for milling was obtained. 


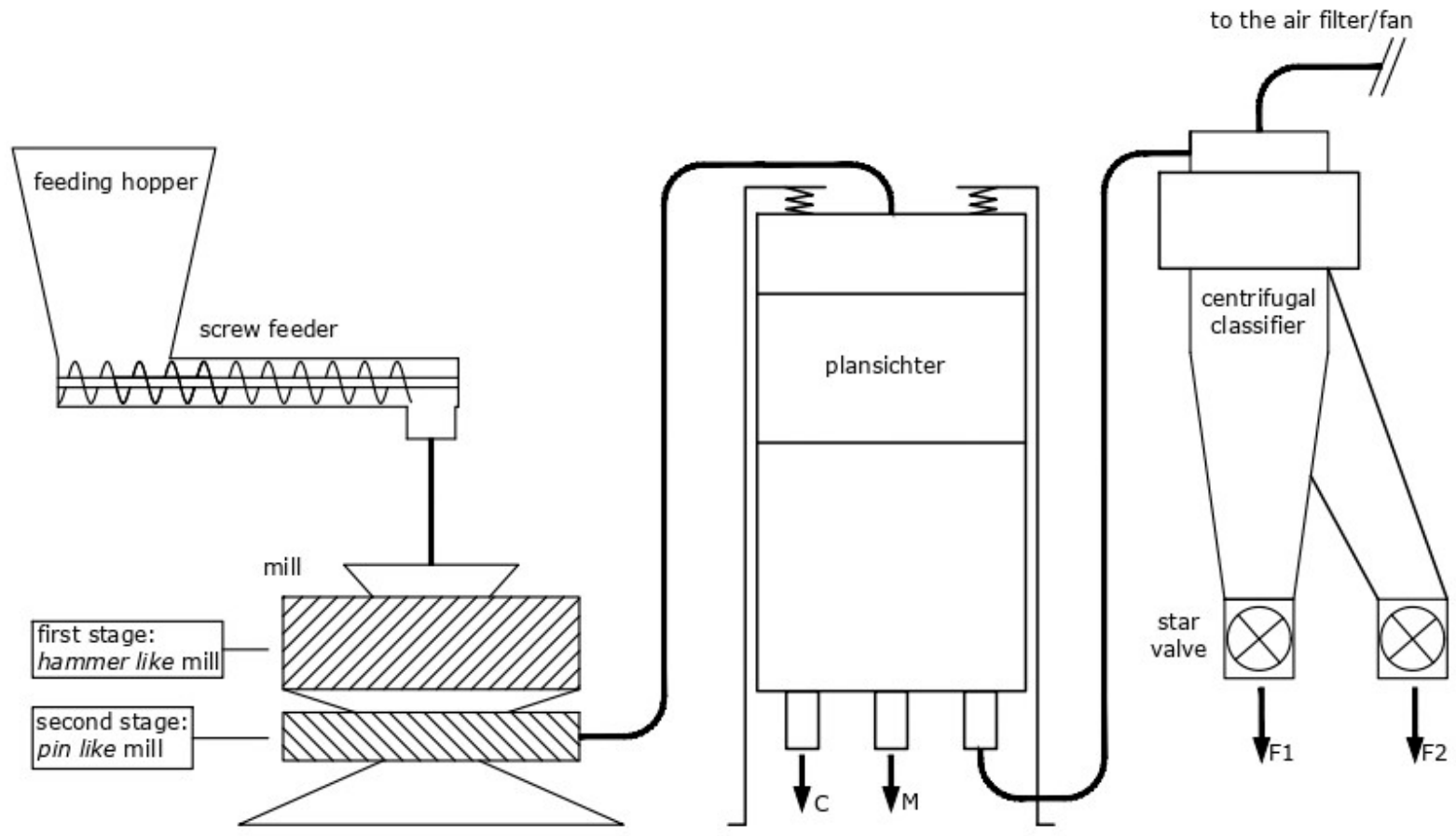

Figure 1. Industrial-scale device from which the different fractions were obtained: C, M, F1, F2.

Table 1. Different fractions obtained.

\begin{tabular}{ccc}
\hline ID & Species & Product \\
\hline HP & hazelnut & Chopped Pruning \\
HC & hazelnut & Coarse \\
HM & hazelnut & Medium \\
HF1 & hazelnut & Fines type 1 \\
HF2 & hazelnut & Fines type 2 \\
OP & olive & Chopped Pruning \\
OC & olive & Coarse \\
OM & olive & Medium \\
OF1 & olive & Fines type 1 \\
OF2 & olive & Fines type 2 \\
\hline
\end{tabular}

\subsection{Chemical and Elemental Composition Analysis}

Both raw and processed materials were analysed for total and volatile solids (TS and VS, respectively) according to APHA standard methods [31]. The final elemental composition (C, N, H) was determined according to ISO 16948:2015; oxygen (O) was determined by difference with $\mathrm{C}, \mathrm{N}$ and $\mathrm{H}$ [32]. The tests were performed in triplicate.

\subsection{Particle Size Analysis}

The particle size of the materials was measured according to the ASABE standard S319.3 [33]. In this test, mass percentages were determined as a function of particle size by passing through sieves of the specified mesh size. A sieve analyser used twelve ISO sieves $(2.000,1.400,1.180,1.000,0.700,0.600,0.500,0.425,0.300,0.212,0.150$ and $0.090 \mathrm{~mm})$. We ran the sieve for $15 \mathrm{~min}$ each time, and the mass of the samples for particle size analysis was about $250 \mathrm{~g}$. 


\subsection{Heating Value}

The higher heating value according to ISO 18125:2017 (HHV, MJ kg $\mathrm{dm}^{-1}$ ) was evaluated, and the lower heating value (LHV) was calculated according to the following equation n $[34,35]$ :

$$
\mathrm{LHV}=(\mathrm{HHV}-2.45 \times 0.09 \cdot \mathrm{H}) \times(1-\mathrm{U})-2.45 \cdot \mathrm{U}\left[\mathrm{MJ} \mathrm{kg}{ }^{-1}\right]
$$

where $2.45 \mathrm{MJ} \mathrm{kg}^{-1}$ is the heat of evaporation of water at $20{ }^{\circ} \mathrm{C}, \mathrm{H}$ and $\mathrm{U}$ the hydrogen and the moisture content $(\%)$. These tests were performed in triplicate.

\subsection{Anaerobic Digestion}

To observe the methane and biogas yields, tests were carried out on samples of raw materials and the F1 and F2 fractions of their processing. The experiments were carried out in batch anaerobic reactors with a working volume of 2 litres and equipped with mixing and thermostating systems; the tests were performed under mesophilic conditions $\left(38{ }^{\circ} \mathrm{C}\right)$. Anaerobic sludge from a mesophilic digester containing 3.67\% total solids (TS) and $2.68 \%$ volatile solids (VS) was used as inoculum. The inoculum/substrate ratio was in the range of 2.04-2.1 on an SV basis, resulting in a substrate loading in the range of 49-50 $\mathrm{g}_{\mathrm{TS}} / \mathrm{L}$. The experiments were carried out in triplicate and lasted 28 days, with two controls using only inoculum sludge; the gas produced by the controls was subtracted from the actual gas produced through media digestion.

Biogas production was measured daily in average samples according to standard methods [31]. The composition of the biogas, with reference to the methane $\left(\mathrm{CH}_{4}\right)$ content, was measured using a portable automatic analyzer SG06IOMX6 (B.A.G.I. srl, Milan, Italy).

\section{Results and Discussion}

Processing of hazelnut pruning gave four products, named HC, HM, HF1 and HF2, whose masses amounted to $8.8 \mathrm{~kg}, 7.0 \mathrm{~kg}, 8.4 \mathrm{~kg}$ and $5.1 \mathrm{~kg}$ respectively, equivalent to $29.5 \%, 23.3 \%, 27.9 \%$ and $17.1 \%$ of the raw material.

Processing of olive pruning gave four products, named OC, OM, OF1 and OF2, whose masses amounted to $8.6 \mathrm{~kg}, 5.2 \mathrm{~kg}, 9.5 \mathrm{~kg}$ and $5.7 \mathrm{~kg}$, respectively, equivalent to $28.6 \%$, $17.5 \%, 31.7 \%$ and $19.0 \%$ of the raw material.

The processing loss was $2.3 \%$ and $3.2 \%$, for hazelnut and olive respectively, mainly due to moisture reduction after milling.

\subsection{Specific Energy Requirement}

The mean power absorbed by the device was $72.0 \mathrm{~kW}$ for hazelnuts, with a specific energy demand of $72.4 \mathrm{kWh} \mathrm{t}^{-1}\left(260.6 \pm 7.3 \mathrm{~kJ} \mathrm{~kg}^{-1}\right)$, and $70.1 \mathrm{~kW}$ for olives, with a specific energy demand of $63.0 \mathrm{kWh} \mathrm{t}^{-1}\left(226.8 \pm 6.9 \mathrm{~kJ} \mathrm{~kg}^{-1}\right)$, including the requirement for the feed conveyor and pneumatic transport of the material.

Additional energy was needed for the preliminary chipping of the raw materials. In this case, the knife mill was manually fed, and therefore, the experimental determination of the specific energy consumption would have been unreliable. Therefore, reference is made to data widely available in the literature, which indicate a consumption of about $15 \mathrm{kWh} \mathrm{t}^{-1}$ of processed material [36-38].

\subsection{Characterization of the Biomasses}

The investigated process significantly modified the nitrogen and ash content of the products with respect to the raw material. In particular, the fractions HC and HM from hazelnut processing showed an ash content of $1.3 \%$ and $1.7 \%$ respectively, far below that of hazelnut pruning, 3.7\% (Table 2). 
Table 2. Moisture and ash of raw and processed pruning. For each sequence, means followed by the same letter in the same column are not statistically different with a $p$-value $<0.05$ (Tukey test).

\begin{tabular}{ccc}
\hline & Moisture [\%] & Ash [\% ${ }_{\text {DM }}$ ] \\
\hline HP & $10.1 \pm 0.6 \mathrm{a}$ & $3.6 \pm 0.3 \mathrm{a}$ \\
HC & $7.9 \pm 0.5 \mathrm{~b}$ & $1.3 \pm 0.2 \mathrm{~b}$ \\
HM & $8.9 \pm 0.2 \mathrm{c}$ & $1.7 \pm 0.2 \mathrm{~b}$ \\
HF1 & $9.4 \pm 0.4 \mathrm{c}$ & $4.0 \pm 0.3 \mathrm{c}$ \\
HF2 & $9.9 \pm 0.4 \mathrm{c}$ & $9.1 \pm 0.2 \mathrm{~d}$ \\
\hline OP & $9.2 \pm 0.5 \mathrm{a}$ & $4.1 \pm 0.2 \mathrm{a}$ \\
OC & $7.9 \pm 0.4 \mathrm{~b}$ & $2.1 \pm 0.2 \mathrm{~b}$ \\
OM & $7.8 \pm 0.2 \mathrm{~b}$ & $2.6 \pm 0.2 \mathrm{~b}$ \\
OF1 & $7.1 \pm 0.4 \mathrm{bc}$ & $5.3 \pm 0.2 \mathrm{c}$ \\
OF2 & $6.8 \pm 0.4 \mathrm{c}$ & $6.1 \pm 0.2 \mathrm{~d}$ \\
\hline
\end{tabular}

The ash content of raw olive was $4.1 \%$, whereas it decreased to $2.1 \%$ and $2.6 \%$ for products OC and OM, respectively. The highest ash concentrations were found in the F1 and F2 products from both materials-3.96\% and 9.08\% in HF1 and HF2, respectively, the last being about 2.5 times the value observed in the raw material, and $5.28 \%$ and $6.15 \%$ in OF1 and OF2 respectively, the last being about 1.5 times the value observed in OP.

The $\mathrm{C}$ and $\mathrm{M}$ fractions from both materials were also notable for the high reduction in the nitrogen content. The product $\mathrm{HC}$ from hazelnut processing showed a nitrogen content of $0.02 \%$, which was only $1 / 36$ of that of the raw material $(0.64 \%)$; the product HM showed a nitrogen content of $0.2 \%$, a third smaller than it was in hazelnut pruning. Particularly concerning olive products, the nitrogen content of OC and OM was $0.07 \%$ and $0.1 \%$ respectively, versus $0.39 \%$ for the raw material.

The nitrogen content significantly increased in both F2 fractions compared to the raw materials, $+73.4 \%$ for hazelnut (HF2) and $+105.1 \%$ for olive (OF2). For olive pruning, the nitrogen in OF1 was $0.41 \%$, slightly higher than $0.38 \%$ observed for the raw material, whereas in HF1, it was slightly lower than that observed in the raw material $(0.54 \%$ vs. $0.64 \%$ ) (Table 3).

Table 3. Elemental analysis of raw and processed pruning. For each sequence, means followed by the same letter in the same column are not statistically different, with a $p$-value $<0.05$ (Tukey test).

\begin{tabular}{|c|c|c|c|c|c|}
\hline & $\mathrm{C}\left[\%_{\mathrm{DM}}\right]$ & $\mathbf{N}\left[\%_{D M}\right]$ & $\mathrm{H}\left[\%_{\mathrm{DM}}\right]$ & $\mathrm{O}\left[\%_{\mathrm{DM}}\right]$ & $\mathrm{C} / \mathrm{N}$ \\
\hline $\mathrm{HP}$ & $42.8 \pm 0.51 \mathrm{a}$ & $0.64 \pm 0.004 \mathrm{a}$ & $5.61 \pm 0.18 \mathrm{a}$ & 50.95 & $66.9 \pm 1.2 \mathrm{a}$ \\
\hline $\mathrm{HC}$ & $41.3 \pm 0.20 \mathrm{~b}$ & $0.02 \pm 0.001 \mathrm{~b}$ & $5.63 \pm 0.07 \mathrm{a}$ & 53.05 & $2367.1 \pm 147 b$ \\
\hline $\mathrm{HM}$ & $43.0 \pm 0.10 \mathrm{a}$ & $0.19 \pm 0.004 c$ & $5.72 \pm 0.11 \mathrm{a}$ & 51.09 & $220.6 \pm 5.0 c$ \\
\hline HF1 & $42.5 \pm 0.32 \mathrm{a}$ & $0.54 \pm 0.003 \mathrm{~d}$ & $5.61 \pm 0.13 a$ & 51.35 & $78.2 \pm 1.0 \mathrm{~d}$ \\
\hline HF2 & $39.3 \pm 0.21 \mathrm{~d}$ & $1.11 \pm 0.003 \mathrm{e}$ & $5.28 \pm 0.09 \mathrm{~d}$ & 54.31 & $35.4 \pm 0.3 \mathrm{e}$ \\
\hline $\mathrm{OP}$ & $42.9 \pm 0.45 \mathrm{ad}$ & $0.39 \pm 0.007 \mathrm{a}$ & $6.54 \pm 0.21 b$ & 50.17 & $110.7 \pm 3.0 \mathrm{a}$ \\
\hline OC & $41.5 \pm 0.31 \mathrm{~b}$ & $0.07 \pm 0.002 b$ & $6.52 \pm 0.09 b$ & 51.91 & $592.2 \pm 21.1 \mathrm{~b}$ \\
\hline $\mathrm{OM}$ & $41.8 \pm 0.59 \mathrm{bc}$ & $0.10 \pm 0.002 c$ & $6.53 \pm 0.12 b$ & 51.57 & $415.5 \pm 14.2 \mathrm{c}$ \\
\hline OF1 & $42.2 \pm 0.44 \mathrm{bc}$ & $0.42 \pm 0.004 \mathrm{~d}$ & $6.55 \pm 0.08 \mathrm{~b}$ & 50.83 & $101.5 \pm 1.9 \mathrm{~d}$ \\
\hline OF2 & $42.6 \pm 0.5 \mathrm{dc}$ & $0.79 \pm 0.005 \mathrm{e}$ & $6.59 \pm 0.15 b$ & 50.02 & $53.6 \pm 1.0 \mathrm{e}$ \\
\hline
\end{tabular}

As regards the carbon content, no relevant differences were observed between the raw materials and their respective products, apart from HF2, whose carbon content was $8.2 \%$ lower than that measured for HP. As a result, the F2 products from both raw materials showed a $\mathrm{C} / \mathrm{N}$ ratio far below those of the untreated pruning, which were excessively high for anaerobic digestion, namely 66.9 and 110.7 for hazelnut and olive, respectively. HF2 from hazelnut reached a value of 35.4, very close to the optimal range for anaerobic digestion (i.e., 20-30:1), whereas the $\mathrm{C} / \mathrm{N}$ ratio was 53.6 for $\mathrm{OF} 2,52.1 \%$ below that of olive pruning. A C/N ratio smaller than that of the raw material was also observed for OF1 (101.5 vs. 110.7), whereas it was higher for HF1, namely 78.2 versus 66.9 for hazelnut pruning. 


\subsection{Biogas Yield and Quality}

The untreated pruning showed a methane yield of $69.4 \mathrm{Nm}^{3} \mathrm{tvs}^{-1}\left( \pm 5.1 \mathrm{Nm}^{3} \mathrm{tvs}^{-1}\right)$ for hazelnut (HP) and $91.2 \mathrm{Nm}^{3} \mathrm{t}_{\mathrm{VS}}{ }^{-1}\left( \pm 5.7 \mathrm{Nm}^{3} \mathrm{t}_{\mathrm{VS}}{ }^{-1}\right)$ with LHV $16.00 \mathrm{MJ} / \mathrm{kg}$, and for olive (OP) with LHV $15.93 \mathrm{MJ} / \mathrm{kg}$ (Tables 4 and 5). The HF2 product from hazelnut processing reached a yield of $118.1 \mathrm{Nm}^{3} \mathrm{t}_{\mathrm{VS}}{ }^{-1}\left( \pm 5.5 \mathrm{Nm}^{3} \mathrm{t}_{\mathrm{VS}}{ }^{-1}\right)$, corresponding to a $+70.1 \%$ gain over the untreated substrate, whereas OF2 from olive reached a yield of $176.5 \mathrm{Nm}^{3} \mathrm{t}_{\mathrm{VS}}{ }^{-1}\left( \pm 4.2 \mathrm{Nm}^{3} \mathrm{t}_{\mathrm{VS}}{ }^{-1}\right)$, corresponding to a $+93.5 \%$ gain over the untreated feedstock (Table 5).

Table 4. Median particle size, higher and lower heating values. Means followed by the same letter in the same column are not statistically different, with a $p$-value $<0.05$ (Tukey test).

\begin{tabular}{cccc}
\hline & $\mathbf{d}_{\mathbf{5 0}}[\boldsymbol{\mu \mathrm { m } ]}$ & HHV $\left[\mathbf{M J} / \mathbf{k g} \mathbf{g}_{\mathbf{D M}}\right]$ & $\mathbf{L H V}[\mathbf{M J} / \mathbf{k g}]$ \\
\hline HP & & $19.3 \pm 2.0 \mathrm{bc}$ & $16.0 \pm 2.1 \mathrm{~b}$ \\
HC & 1600 & $19.0 \pm 0.3 \mathrm{~b}$ & $16.3 \pm 0.7 \mathrm{~b}$ \\
HM & 700 & $20.1 \pm 0.3 \mathrm{c}$ & $16.9 \pm 0.6 \mathrm{~b}$ \\
HF1 & 310 & $19.8 \pm 0.3 \mathrm{c}$ & $16.6 \pm 0.6 \mathrm{~b}$ \\
HF2 & 180 & $18.2 \pm 0.4 \mathrm{~b}$ & $15.3 \pm 0.7 \mathrm{~b}$ \\
\hline OP & & $19.2 \pm 1.0 \mathrm{~d}$ & $15.9 \pm 1.3 \mathrm{c}$ \\
OC & 1800 & $19.2 \pm 0.3 \mathrm{~d}$ & $16.2 \pm 0.6 \mathrm{c}$ \\
OM & 750 & $19.2 \pm 0.1 \mathrm{~d}$ & $16.2 \pm 0.6 \mathrm{c}$ \\
OF1 & 300 & $19.2 \pm 0.2 \mathrm{~d}$ & $16.3 \pm 0.5 \mathrm{c}$ \\
OF2 & 160 & $20.0 \pm 0.1 \mathrm{~d}$ & $17.1 \pm 0.5 \mathrm{c}$ \\
\hline
\end{tabular}

Table 5. Methane yield and biogas composition for raw and processed pruning. Values followed by the same letter in the same column are not statistically different, with a $p$-value $<0.05$ (Tukey test).

\begin{tabular}{cccc}
\hline & BMP-CH $_{4}\left[\mathbf{N m}^{3} / \mathbf{t}\right]$ & $\mathbf{B M P} \mathbf{C H}_{4}\left[\mathbf{N m}^{3} / \mathbf{t}_{\text {Sv }}\right]$ & ${ }_{0} \mathbf{C H}_{4}\left[\mathbf{N m}^{3} / \mathbf{t}_{\text {SV }}\right]$ \\
\hline HP & $59.8 \pm 4.5 \mathrm{a}$ & $69.4 \pm 5.1 \mathrm{a}$ & $49.8 \pm 0.4 \mathrm{a}$ \\
$\mathrm{HF} 1$ & $67.3 \pm 3.6 \mathrm{a}$ & $78.7 \pm 4.0 \mathrm{a}$ & $50.0 \pm 0.1 \mathrm{a}$ \\
$\mathrm{HF} 2$ & $96.8 \pm 3.8 \mathrm{~b}$ & $118.1 \pm 4.2 \mathrm{~b}$ & $49.8 \pm 0.1 \mathrm{a}$ \\
\hline OP & $79.4 \pm 5.4 \mathrm{a}$ & $91.2 \pm 5.7 \mathrm{a}$ & $49.3 \pm 0.4 \mathrm{a}$ \\
OF1 & $101.3 \pm 4.7 \mathrm{~b}$ & $115.6 \pm 4.9 \mathrm{~b}$ & $49.7 \pm 0.1 \mathrm{a}$ \\
OF2 & $153.8 \pm 4.4 \mathrm{c}$ & $176.5 \pm 4.2 \mathrm{c}$ & $50.4 \pm 0.2 \mathrm{~b}$ \\
\hline
\end{tabular}

OF1 showed a biomethane yield gain, namely $+26.7 \%$, compared with the raw material. No statistically significant yield gain was observed for HF1. Except for OF2, no statistically significant differences were observed in the chemical composition of the biogas, whose methane content in the biogas was $50.4 \%$ and $49.3 \%$ in the feedstock.

As expected, methane production was faster in the processed material than in the untreated feedstock. HF2 reached $50 \%$ of the cumulative production during the third day from the start of the test (Figure 2). HF1 reached the same amount during the 4th day, while $\mathrm{HP}$ took about 5 days. OF2 and OF1 reached $50 \%$ of the cumulative production during the 8th day of digestion, while OP took approximately 11 days (Figure 3).

The methane production rate for the F2 fractions was high, reaching the maximum of about $17.5 \mathrm{Nm}^{3} \mathrm{t}_{\mathrm{VS}}{ }^{-1}$ day $^{-1}$ between the 2 nd and 3rd day of digestion for HF2, whereas the maximum for OF2 was about $15 \mathrm{Nm}^{3} \mathrm{tVs}_{\mathrm{VS}}{ }^{-1}$ day $^{-1}$ during the $3 \mathrm{rd}$ day of digestion. Regarding feedstock, maximum production rates were only $11.1 \mathrm{Nm}^{3} \mathrm{tVs}^{-1}$ day $^{-1}$ and $6.4 \mathrm{Nm}^{3} \mathrm{t}_{\mathrm{VS}}{ }^{-1}$ day $^{-1}$ for hazelnut and olive, respectively. 


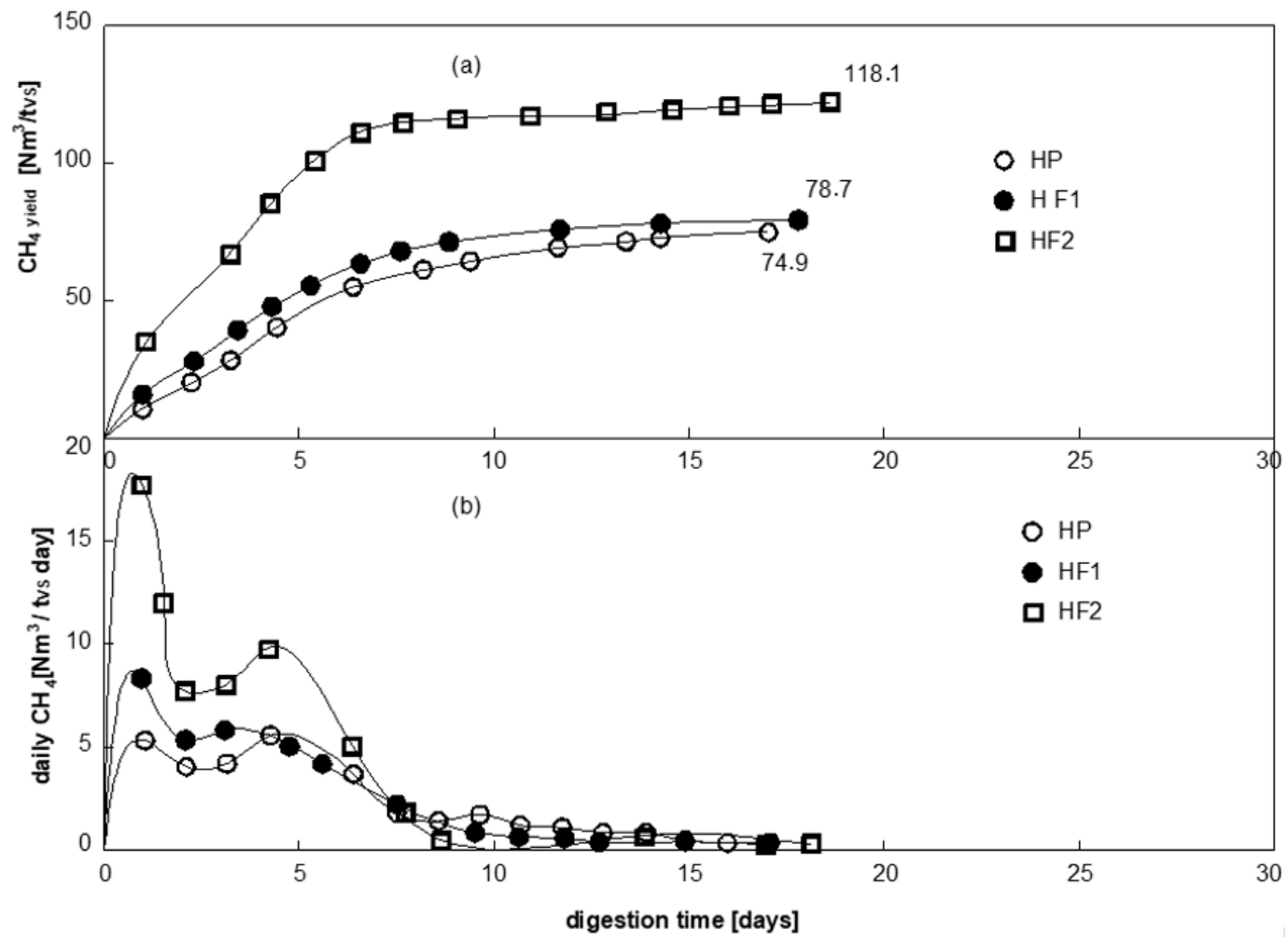

Figure 2. Cumulative methane yield of hazelnut pruning and fraction HF1 and HF2 from processing (a) and daily methane yield (b).

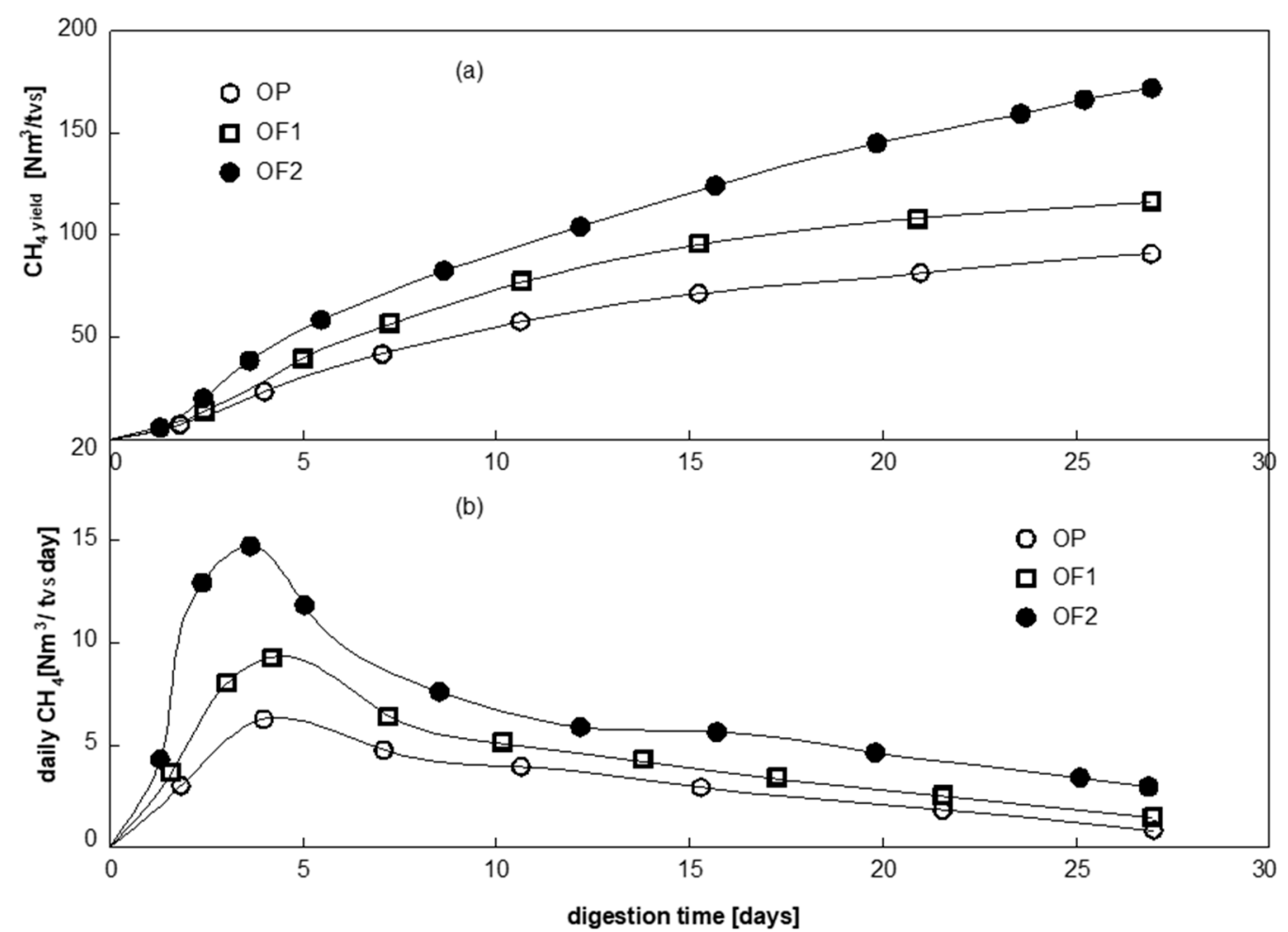

Figure 3. Cumulative methane yield of olive pruning and fraction OF1 and OF2 from processing (a) and daily methane yield (b). 


\subsection{Higher and Lower Heating Values}

There were no statistically significant differences between the higher and lower heating values of the feedstock and those of their respective products (Table 4).

\section{Discussion}

The investigated process enhanced the pruning quality as solid fuel, allowing their convenient use in pellet supply chains, and it was also effective in producing biomass with highly improved anaerobic digestibility.

The products $\mathrm{C}$ and $\mathrm{M}$ from both the feedstock showed an improved quality as solid fuel, since they had a highly reduced ash content compared with the raw material. Ash adversely affects the calorific value, the dust emissions and the combustion plant performance because of the formation of unburnt material, accompanied by corrosion, erosion and fouling; they showed a highly reduced nitrogen content compared with the raw pruning, and nitrogen is an undesired element since in the combustion process it generates nitrogen oxides, responsible for irritant effects on humans and the formation of photochemical smog [39]. In small-scale combustion systems in which the flue gas temperature are above $1300{ }^{\circ} \mathrm{C}$ nitrogen oxides are assumed to be formed mainly from fuel nitrogen during biomass combustion [40].

Both HP and OP did not meet the specification for industrial pellets given in the EN ISO 17225-2 standard [41], because their ash content was too high for OP and their nitrogen and ash contents were too high for HP. The LHVs of both the feedstock were slightly below the lower limit $\left(16 \mathrm{MJ} \mathrm{kg}^{-1}\right)$ given in the standard; however, this was due to the high amount of moisture in the raw materials, namely $10.1 \%$ and $9.25 \%$ for HP and $\mathrm{OP}$, respectively. Likewise, both $\mathrm{HP}$ and $\mathrm{OP}$ did not meet the specification for residential pellets given in the EN ISO 17225-2 [41], because their ash content exceeded the limit of $2 \%$ stated for the lower class B (Table 6), as was also observed by Stelte et al. (2011) [42]. However, the operating parameters should be considered in a possible combustion process, as highlighted by Venturini et al. (2018). In order to limit pollutant emissions from pellet boilers, it is important to consider the quality of the pellets, but attention should also be paid to the combustion conditions of the stove, as the formation of pollutants such as carbon compounds or polycyclic aromatic hydrocarbons seem to be influenced by the heat output of the boiler [43].

Table 6. Compliance of raw pruning and respective products $C$ and $M$ with the European standard EN ISO 17225-2 for industrial and residential use. I1, I2, I3, A1, A2, B represent the quality categories of pellets, I for industrial and A/B for residential.

\begin{tabular}{cccccc}
\hline & & Moisture \% & LHV MJ/kg & Ash \% & N \% \\
\hline \multirow{2}{*}{ ISO 17225-2 industrial pellets } & I1 & $\leq 10$ & $\geq 16.5$ & $\leq 1$ & $\leq 0.3$ \\
& I2 & $\leq 10$ & $\geq 16.5$ & $\leq 1.5$ & $\leq 0.3$ \\
ISO 17225-2 non industrial pellets & I3 & $\leq 10$ & $\geq 16.5$ & $\leq 3$ & $\leq 0.6$ \\
& A2 & $\leq 10$ & $\geq 16.5$ & $\leq 0.7$ & $\leq 0.3$ \\
& B & $\leq 10$ & $\geq 16.5$ & $\leq 1.2$ & $\leq 0.5$ \\
& HP & 10.1 & $\geq 16.5$ & $\leq 2$ & $\leq 1$ \\
Hazelnut & HC & 7.4 & 16.0 & 3.6 & 0.6 \\
& HM & 8.9 & 16.3 & 1.3 & 0.0 \\
& OP & 9.2 & 15.9 & 4.1 & 0.2 \\
& OC & 7.9 & 16.2 & 2.1 & 0.4 \\
& OM & 7.8 & 16.2 & 2.6 & 0.1 \\
\hline
\end{tabular}

On the other hand, the nitrogen content met the requirement of class B for HP and class A2 for OP. In order to meet the minimum lower heating value required by the standard, a moisture content between $6 \%$ and $7 \%$ is needed for hazelnut pruning and no more than $6 \%$ for olive pruning.

With regard to products, $\mathrm{HM}$ from hazelnut processing met the requirements of class $\mathrm{B}$ for residential pellets and class $\mathrm{I} 3$ for industrial pellets. In both cases, the limiting factor was the ash content at $1.73 \%$, which too high to achieve class A2 for residential use (upper limit 1.2\%) and class I2 for industrial use (upper limit 1.5\%) [41]. With the exception of the 
lower heating value, slightly lower than $16.5 \mathrm{MJ} \mathrm{kg}^{-1}$, $\mathrm{HC}$ met the requirements of class B for residential pellets and class I2 for industrial use. The limiting factor was the ash content. For both HC and HM, the nitrogen content was far below the upper limit permitted for the top classes A1 and I1, whereas the raw material did not comply with the EU standard.

With the exception of the lower heating values, products OC and OM from olive processing met the requirements for the industrial class I3. However, they did not meet the requirements for residential pellet, the limiting factor being the ash content at $2.09 \%$ and $2.56 \%$, respectively, too high for the $2 \%$ upper limit required for the lower class $B$. In this case as well, the nitrogen content was far below the upper limit permitted for the top classes.

The fine fractions F1 and F2 from both feedstock were suitable for the biochemical conversion by anaerobic digestion. The high concentration of nitrogenous matter made their $\mathrm{C} / \mathrm{N}$ ratios smaller than those of the respective raw materials and far better for anaerobic digestion. As is well known, a 20-30:1 ratio of $C$ to $N$ is needed for optimal anaerobic digestion, since microorganisms utilize carbon 25-30 times faster than nitrogen [44]. In particular, HF2 reached a ratio of 35.4, very close to the optimal range, with a reduction of about $49 \%$ compared with HP. The methane yield reached $118.1 \mathrm{Nm}^{3} \mathrm{tvS}^{-1}$, corresponding to a $+70.1 \%$ gain over the untreated substrate, whereas for $\mathrm{OF} 2$, the $\mathrm{C} / \mathrm{N}$ ratio was 53.6 , with a reduction of about $59.6 \%$, and the methane production was very high, reaching $176.5 \mathrm{Nm}^{3} \mathrm{tVs}^{-1}$, corresponding to a yield gain of about $+93.5 \%$ over the untreated raw material. Serrano et al. (2019) report methane production rates of $163 \pm 28 \mathrm{~mL} \mathrm{CH} 4 /\left(\mathrm{g}_{\mathrm{vs}} \cdot \mathrm{d}\right)$ for Olive Mill Solid Waste, which confirms the excellent potential of these raw materials [20]. Weide et al. (2019) also showed that the addition of agricultural wastes such as grass silage, maize silage, chicken manure, triticale straw, maize straw, horse manure, and hay can increase biomethane yields, also by regulating the intervention of enzymes in the process [45].

Biomethane yield of OF1 increased compared with the raw material $(+26.7 \%)$, corresponding to a slight reduction of the $\mathrm{C} / \mathrm{N}$ ratio, which was $101.5 \mathrm{vs.} 110.7$ of the feedstock. For HF1, the methane production was $78.7 \mathrm{Nm}^{3} \mathrm{t}_{\mathrm{VS}}{ }^{-1}$ and there was no statistically significant difference compared to the raw material $69.4 \mathrm{Nm}^{3} \mathrm{tVs}_{\mathrm{Vs}}{ }^{-1}$; however, the production was significantly faster. The $\mathrm{C} / \mathrm{N}$ ratio of HF1 was slightly higher than that of the raw material (78.2 vs. 66.9).

The process revealed a low energy consumption, which was $85.1 \mathrm{kWh} \mathrm{t}^{-1}$ to $87.4 \mathrm{kWh} \mathrm{t}^{-1}$ for olive and hazelnut pruning, respectively. In order to assess its energy efficiency, we compared the energy consumption with the energy output from the products F1 and F2 after anaerobic digestion and electric energy production through a standard $\mathrm{CHP}$ engine. Under the assumption of a conversion rate of $4 \mathrm{kWh}\left(\mathrm{m}^{3} \mathrm{CH}_{4}\right)^{-1}$, the energy output from the methane was $168.6 \mathrm{kWh}$ per processed ton of hazelnut pruning and $245.3 \mathrm{kWh} \mathrm{t}^{-1}$ for olive, which made the energy balance largely positive. Under the further assumptions that the sell price for F1 and F2 was $0.45 \mathrm{EUR} / \mathrm{m}^{3} \mathrm{CH}_{4}$-the standard value for corn silage-their overall market value was EUR 19 per ton of processed hazelnut pruning and 27.6 EUR/t for olive pruning. Therefore, they exceeded the energy cost of the process, which was $15.7 \mathrm{EUR} / \mathrm{t}$ and $15.3 \mathrm{EUR} / \mathrm{t}$ for hazelnut and olive pruning respectively, assuming $0.18 \mathrm{EUR} \mathrm{kWh}^{-1}$ the cost for electric energy. It is interesting to note that more and more studies are finding the potential of pruning waste, as observed by Maccarini et al. (2020), who, with pruning waste from the urban environment, estimated the potential production of $1.406 \mathrm{MWe}$, with 6.77 tons day ${ }^{-1}$ of residues in eight hours per day, generated using standard CHP engines [46].

These results suggest that the investigated process could be successfully used to improve the quality of pruning and establish new markets for them.

\section{Conclusions}

Orchard prunings are well known for their poor quality as a fuel, especially in smallscale boilers, mainly due to the high ash and nitrogen content. A mechanical, commercial- 
scale process was investigated for treating hazelnut and olive pruning through multiple milling stages and subsequent classification into four different products. The coarser products ( $\mathrm{C}$ and $\mathrm{M}$ ) showed reduced ash and nitrogen content. Thus, hazelnut met the ISO 17225-2 parameters for both industrial and residential pellets, and olive met the parameters for industrial pellets only.

The fine fractions F1 and F2 from both feedstock were suitable for the biochemical conversion by anaerobic digestion, due to the high concentration of nitrogenous matter, which made their $\mathrm{C} / \mathrm{N}$ ratios smaller than those of the respective raw materials. In particular, the methane yield of the finest products from processing was $118.1 \mathrm{Nm}^{3} \mathrm{t}_{\mathrm{VS}}{ }^{-1}$ for hazelnut, corresponding to $\mathrm{a}+70.1 \%$ gain over the untreated substrate, and $176.5 \mathrm{Nm}^{3} \mathrm{t}_{\mathrm{VS}}{ }^{-1}$ for olive, corresponding to a yield gain of about $+93.5 \%$ over the untreated raw material.

The energy efficiency of the process was assessed, and it was largely positive considering only the electric energy output from the methane. Likewise, the overall market value of the product for anaerobic digestion exceeded the energy cost needed to process the raw materials.

These results suggest that the investigated process could be successfully used to improve the quality of pruning and establish new markets for them. Moreover, products suitable for anaerobic digestion and the production of advanced biomethane can be generated.

Author Contributions: Conceptualization, P.C., P.P.D. and A.C.; methodology, P.C. and M.C.; software, P.C. and M.C.; validation, P.P.D. and D.M.; formal analysis, P.C. and P.P.D.; investigation, P.C. and A.C.; resources, P.C. and A.C.; data curation, P.P.D. and L.B.; writing-original draft preparation, P.P.D. and A.C.; writing-review and editing, P.P.D., P.C., A.C. and L.B.; visualization, A.C., P.P.D. and L.B.; supervision, M.C., P.C. and P.P.D.; project administration, D.M., P.C. and A.C. All authors have read and agreed to the published version of the manuscript.

Funding: This research received no external funding.

Institutional Review Board Statement: Not applicable.

Informed Consent Statement: Not applicable.

Data Availability Statement: Data not available.

Conflicts of Interest: The authors declare no conflict of interest.

\section{References}

1. Commission, E. Communication From the Commission To the Council and the European Parliament, Renewable energy road map-Renewable energies in the 21st century: Building a more sustainable future. COM 2006, 848, EUR-Lex-52006DC0848EN-EUR-Lex. Available online: https:/ / eur-lex.europa.eu/legal-content/HR/TXT/?uri=CELEX:52006DC0848 (accessed on 7 January 2021).

2. Zambon, I.; Colosimo, F.; Monarca, D.; Cecchini, M.; Gallucci, F.; Proto, A.R.; Lord, R.; Colantoni, A. An innovative agro-forestry supply chain for residual biomass: Physicochemical characterisation of biochar from olive and hazelnut pellets. Energies 2016, 9, 526. [CrossRef]

3. ARSIA. The Wood-Energy Chain. Final Results from the Interregional Project Woodland Energy; Regione Toscana: Firenze, Italy, 2009; ISBN 978-88-8295-106-1. (In Italian)

4. Spinelli, R.; Picchi, G. Industrial harvesting of olive tree pruning residue for energy biomass. Bioresour. Technol. 2010, 101, 730-735. [CrossRef] [PubMed]

5. Fedrizzi, M.; Sperandio, G.; Pagano, M.; Pochi, D.; Fanigliulo, R. A Prototype Machine for Harvesting and Chipping of Pruning Residues: First test on Hazelnut Plantation (Corylus avellana L.) A Prototype Machine for Harvesting and Chipping of Pruning Residues: First test on Hazelnut Plantation (Corylus avellana L.). Energy Biomass Biol. Residues. Int. Conf. Agric. Eng. CIGR AgEng Agric. Eng. Heal. Life Val. Spain 2012, 7, 1301.

6. Bernetti, I.; Fagarazzi, C.; Fratini, R. A methodology to anaylse the potential development of biomass-energy sector: An application in Tuscany. For. Policy Econ. 2004, 6, 415-432. [CrossRef]

7. Monarca, D.; Cecchini, M.; Colantoni, A.; Di Giacinto, S.; Marucci, A.; Longo, L. Assessment of the energetic potential by hazelnuts pruning in Viterbo?s area. J. Agric. Eng. 2013, 44, 10-13. [CrossRef]

8. Torquati, B.; Marino, D.; Venanzi, S.; Porceddu, P.R.; Chiorri, M. Using tree crop pruning residues for energy purposes: A spatial analysis and an evaluation of the economic and environmental sustainability. Biomass Bioenergy 2016, 95, 124-131. [CrossRef] 
9. Velázquez-Martí, B.; Fernández-González, E.; López-Cortés, I.; Salazar-Hernández, D.M. Quantification of the residual biomass obtained from pruning of trees in Mediterranean olive groves. Biomass Bioenergy 2011, 35, 3208-3217. [CrossRef]

10. Garcia-Maraver, A.; Zamorano, M.; Fernandes, U.; Rabaçal, M.; Costa, M. Relationship between fuel quality and gaseous and particulate matter emissions in a domestic pellet-fired boiler. Fuel 2014, 119, 141-152. [CrossRef]

11. Vega-Nieva, D.J.; Ortiz Torres, L.; Míguez Tabares, J.L.; Morán, J. Measuring and Predicting the Slagging of Woody and Herbaceous Mediterranean Biomass Fuels on a Domestic Pellet Boiler. Energy Fuels 2016, 30, 1085-1095. [CrossRef]

12. Arranz, J.I.; Miranda, M.T.; Montero, I.; Sepúlveda, F.J.; Rojas, C.V. Characterization and combustion behaviour of commercial and experimental wood pellets in South West Europe. Fuel 2015, 142, 199-207. [CrossRef]

13. Carvalho, L.; Wopienka, E.; Pointner, C.; Lundgren, J.; Verma, V.K.; Haslinger, W.; Schmidl, C. Performance of a pellet boiler fired with agricultural fuels. Appl. Energy 2013, 104, 286-296. [CrossRef]

14. Picchi, G.; Silvestri, S.; Cristoforetti, A. Vineyard residues as a fuel for domestic boilers in Trento Province (Italy): Comparison to wood chips and means of polluting emissions control. Fuel 2013, 113, 43-49. [CrossRef]

15. Lehtikangas, P. Quality properties of pelletised sawdust, logging residues and bark. Biomass Bioenergy 2001, 20, 351-360. [CrossRef]

16. Samson, R.; Lem, C.H.; Stamler, S.B.; Dooper, J. Developing energy crops for thermal applications: Optimizing fuel quality, energy security and GHG mitigation. In Biofuels, Solar and Wind as Renewable Energy Systems: Benefits and Risks; Springer: Amsterdam, The Netherlands, 2008; pp. 395-423, ISBN 9781402086533.

17. Bordelanne, O.; Montero, M.; Bravin, F.; Prieur-Vernat, A.; Oliveti-Selmi, O.; Pierre, H.; Papadopoulo, M.; Muller, T. Biomethane CNG hybrid: A reduction by more than $80 \%$ of the greenhouse gases emissions compared to gasoline. J. Nat. Gas. Sci. Eng. 2011, 3, 617-624. [CrossRef]

18. Ministero dello sviluppo economico Decreto 10 ottobre 2014. Aggiornamento delle condizioni, dei criteri e delle modalità di attuazione dell'obbligo di immissione in consumo di biocarburanti compresi quelli avanzati. Gazz. Uff. Della Repubb. Ital. 2014, $250,81-88$.

19. GSE Fonti Rinnovabili in Italia e nelle Regioni-Rapporto di Monitoraggio 2012-2018. Available online: https://www.gse.it/ documenti_site/DocumentiGSE/Rapportistatistici/RapportodiMonitoraggiodicuialDM11-5-15art7_anni2012-2018.pdf (accessed on 30 January 2021).

20. Serrano, A.; Fermoso, F.G.; Alonso-Fariñas, B.; Rodríguez-Gutiérrez, G.; López, S.; Fernandez-Bolaños, J.; Borja, R. Long-term evaluation of mesophilic semi-continuous anaerobic digestion of olive mill solid waste pretreated with steam-explosion. Energies 2019, 12, 2222. [CrossRef]

21. Şenol, H. Biogas potential of hazelnut shells and hazelnut wastes in Giresun City. Biotechnol. Rep. 2019, 24, e00361. [CrossRef] [PubMed]

22. Kabir, M.M.; Rajendran, K.; Taherzadeh, M.J.; Sárvári Horváth, I. Experimental and economical evaluation of bioconversion of forest residues to biogas using organosolv pretreatment. Bioresour. Technol. 2015, 178, 201-208. [CrossRef]

23. Shafiei, M.; Karimi, K.; Zilouei, H.; Taherzadeh, M.J. Enhanced ethanol and biogas production from pinewood by NMMO pretreatment and detailed biomass analysis. Biomed. Res. Int. 2014. [CrossRef]

24. Nitsos, C.; Matsakas, L.; Triantafyllidis, K.; Rova, U.; Christakopoulos, P. Evaluation of mediterranean agricultural residues as a potential feedstock for the production of biogas via anaerobic fermentation. Biomed. Res. Int. 2015, 2015. [CrossRef]

25. Barakat, A.; de Vries, H.; Rouau, X. Dry fractionation process as an important step in current and future lignocellulose biorefineries: A review. Bioresour. Technol. 2013, 134, 362-373. [CrossRef] [PubMed]

26. Pelgrom, P.J.M.; Vissers, A.M.; Boom, R.M.; Schutyser, M.A.I. Dry fractionation for production of functional pea protein concentrates. Food Res. Int. 2013, 53, 232-239. [CrossRef]

27. Dell'Omo, P.; Luciani, F.; Preti, R.; Vinci, G. Hypercritical separation technology (HYST): A sustainable technology for agricultural by-products valorization. In Pathways to Environmental Sustainability: Methodologies and Experiences; Springer International Publishing: Berlin/Heidelberg, Germany, 2014; pp. 53-63, ISBN 9783319038261.

28. Murthy, G.S.; Singh, V.; Johnston, D.B.; Rausch, K.D.; Tumbleson, M.E. Evaluation and Strategies to Improve Fermentation Characteristics of Modified Dry-Grind Corn Processes. Cereal Chem. J. 2006, 83, 455-459. [CrossRef]

29. Papatheofanous, M.G.; Billa, E.; Koullas, D.P.; Monties, B.; Koukios, E.G. Optimizing Multisteps Mechanical-Chemical Fractionation of Wheat Straw Components. Ind. Crops Prod. 1998, 7, 249-256. [CrossRef]

30. Manola, U. Biomass Crushing and Separating Device. 2010. Available online: https://patents.google.com/patent/US9266113B2 /en (accessed on 15 January 2021).

31. Rice, E.W.; Baird, R.B.; Eaton, A.D. Standard Methods for the Examination of Water and Wastewater, 23rd ed.; American Public Health Association: Washington, DC, USA, 2005; ISBN 9780875532875.

32. ISO. ISO 16948:2015 Solid Biofuels-Determination of Total Content of Carbon, Hydrogen and Nitrogen. 2015. Available online: http: / / store.uni.com/catalogo/en-iso-16948-2015 (accessed on 19 January 2021).

33. ASAE Methods for Determining and Expressing Fineness of Feed Materials by Sieving. 1995. Available online: https://elibrary. asabe.org/standards.asp (accessed on 19 January 2021).

34. ISO. ISO 18125:2017-Solid Biofuels-Determination of Calorific Value. Available online: https://www.iso.org/standard/6151 7.html\#: \{\}:text=Solid\%20biofuels\%20\%E2\%80\%94\%20Determination\%20of\%20calorific\%20value, Buy \%20this\%20standard\& text=ISO \%2018125\%3A2017\%20specifies\%20a,combustion\%20of\%20certified\%20benzoic\%20acid. (accessed on 30 January 2021). 
35. Colantoni, A.; Longo, L.; Gallucci, F.; Monarca, D. Pyro-gasification of hazelnut pruning using a downdraft gasifier for concurrent production of syngas and biochar. Contemp. Eng. Sci. 2016, 9, 1339-1348. [CrossRef]

36. Monarca, D.; Cecchini, M.; Colantoni, A. Plant for the Production of Chips and Pellet: Technical and Economic Aspects of an Case Study in the Central Italy. In Proceedings of the Lecture Notes in Computer Science (including subseries Lecture Notes in Artificial Intelligence and Lecture Notes in Bioinformatics), San Jose, CA, USA; 2011; Volume 6785, pp. $296-306$.

37. Boubaker, K.; de Franchi, M.; Colantoni, A.; Monarca, D.; Cecchini, M.; Longo, L.; Allegrini, E.; Di Giacinto, S.; Biondi, P.; Menghini, G. Prospective for hazelnut cultivation small energetic plants outcome in Turkey: Optimization and inspiration from an Italian model. Renew. Energy 2015, 74, 523-527. [CrossRef]

38. Monarca, D.; Cecchini, M.; Guerrieri, M.; Colantoni, A. Conventional and alternative use of biomasses derived by hazelnut cultivation and processing. Acta Hortic. 2009, 845, 627-634. [CrossRef]

39. Colantoni, A.; Paris, E.; Bianchini, L.; Ferri, S.; Marcantonio, V.; Carnevale, M.; Palma, A. Spent coffee ground characterization, pelletization test and emissions assessment in the combustion process. Sci. Rep. 2021, 1-14. [CrossRef]

40. Lukáč, L.; Rimár, M.; Variny, M.; Kizek, J.; Lukáč, P.; Jablonskỳ, G.; Janošovskỳ, J.; Fedák, M. Experimental investigation of primary de-NOx methods application effects on NOx and CO emissions from a small-scale furnace. Processes 2020, 8. [CrossRef]

41. ISO 17225-2:2014-Solid Biofuels-Fuel Specifications and Classes-Part 2: Graded Wood Pellets. 2014. Available online: http: / / store.uni.com/catalogo/iso-17225-2-2014 (accessed on 22 January 2021).

42. Stelte, W.; Holm, J.K.; Sanadi, A.R.; Barsberg, S.; Ahrenfeldt, J.; Henriksen, U.B. A study of bonding and failure mechanisms in fuel pellets from different biomass resources. Biomass Bioenergy 2011, 35, 910-918. [CrossRef]

43. Venturini, E.; Vassura, I.; Agostini, F.; Pizzi, A.; Toscano, G.; Passarini, F. Effect of fuel quality classes on the emissions of a residential wood pellet stove. Fuel 2018, 211, 269-277. [CrossRef]

44. Bardiya, N.; Gaur, A.C. Effects of carbon and nitrogen ratio on rice straw biomethanation. J. Rural Energy 1997, 4, 1-16.

45. Weide, T.; Baquero, C.D.; Schomaker, M.; Brügging, E.; Wetter, C. Effects of enzyme addition on biogas and methane yields in the batch anaerobic digestion of agricultural waste (silage, straw, and animal manure). Biomass Bioenergy 2020, 132, 105442. [CrossRef]

46. Maccarini, A.C.; Bessa, M.R.; Errera, M.R. Energy valuation of urban pruning residues feasibility assessment. Biomass Bioenergy 2020, 142, 105763. [CrossRef] 